\title{
A progestagen-dependent endometrial protein in human amniotic fluid
}

\author{
S. G. Joshi, R. A. Smith and D. K. Stokes* \\ Department of Obstetrics and Gynecology, The Neil Hellman Medical Research Building, \\ Albany Medical College, Albany, New York 12208, U.S.A.
}

\begin{abstract}
Summary. A protein was detected in human amniotic fluid that had properties identical to those of the progestagen-dependent endometrial protein. The concentration of the amniotic fluid protein was maximal during Weeks 15-18 of pregnancy and then declined rapidly. The protein was not detected in immature and mature placentae, ovary, Fallopian tube, myometrium and cervix. We conclude that a specific protein synthesized by the human uterine decidua is transported to the amniotic sac.
\end{abstract}

\section{Introduction}

Studies of the soluble proteins in human amniotic fluid and their tissues of origin have been undertaken by several investigators in an attempt to identify proteins which may serve as markers for the diagnosis of genetic disease and abnormal fetal growth. Such studies have shown that the fetal tissues do contribute a small but significant extent to the protein content of amniotic fluid. However, nearly all the proteins in amniotic fluid are derived from maternal blood (Sutcliffe, 1975) and very few non-serum proteins have been detected. We have been investigating the possibility that proteins of the uterine decidua of pregnancy are transported to the amniotic sac via the chorion and amnion, and that the analysis of such proteins in amniotic fluid may provide valuable information about endometrial development during normal and abnormal pregnancy in women. We have previously shown that the human decidua of pregnancy synthesizes a progestagen-dependent protein (Joshi, Ebert \& Swartz, 1980a). This paper deals with the detection and quantitation of this protein of decidual origin in human amniotic fluid.

\section{Materials and Methods}

Samples of uncontaminated amniotic fluid were obtained from 97 women who underwent amniocentesis for diagnosis of genetic diseases or for fetal maturity studies, and from women who elected to terminate mid-trimester pregnancy by intra-amniotic injection of hypertonic saline. Samples were obtained during Weeks $13 \cdot 5-20(\mathrm{~N}=70), 24-30(\mathrm{~N}=6)$, and 31-40 $(\mathrm{N}=21)$ of pregnancy. Amniotic fluid samples were centrifuged $(850 \mathrm{~g}, 20 \mathrm{~min})$ at $4^{\circ} \mathrm{C}$ and the clear supernatants were stored at $-20^{\circ} \mathrm{C}$ until used.

Blood samples from several adult, healthy males were pooled and the serum was used for the absorption of the pool of rabbit antisera.

* Present address: Department of Reproductive Medicine, University of California at San Diego, California 92103 , U.S.A. 
Decidua-rich tissue and placental villous tissue (immature placenta) were obtained from women who had undergone elective termination of early pregnancy (5-10 weeks) by menstrual induction. Samples of mid-term (16-20 weeks) placentae were obtained from 15 women who had undergone prostaglandin-induced abortion. Specimens of term placentae were also procured from 10 women following normal vaginal delivery at term. In addition pieces of ovary (containing follicle or corpus luteum), Fallopian tube, myometrium and cervix were excised from the total abdominal hysterectomy specimens obtained from 7 women in the luteal phase and from 5 women in the follicular phase of the menstrual cycle. The tissues were washed with saline $(9 \mathrm{~g} \mathrm{NaCl} / \mathrm{l})$, homogenized in $0.1 \mathrm{M}$-Tris- $\mathrm{HCl}$ buffer, $\mathrm{pH} 7.4$, and the homogenates were centrifuged $(110000 \mathrm{~g}, 90 \mathrm{~min})$ to obtain cytosols. Aliquots of the cytosols were stored at $-20^{\circ} \mathrm{C}$ until used.

Proteins of tissue cytosols were fractionated by Concanavalin A-Sepharose (Con A-Sepharose) chromatography, polyacrylamide gel electrophoresis (PAGE) and by isoelectric focussing on thin layers of acrylamide gels, as described by Joshi, Ebert \& Smith (1980b).

The progestagen-dependent proteins in the amniotic fluid samples and decidual cytosols were detected by the double immunodiffusion test, using a pool of the antisera that were produced in rabbits against a partly purified progestagen-dependent protein of the decidua-rich tissues and absorbed with quality control male serum as described by Joshi $e$ t al. (1980b). The antiserum used in this study reacted with the cytosols of the decidua of pregnancy or of the secretory endometria of cyclic women with the formation of a single diffuse precipitin line corresponding to the progestagen-dependent protein (Text-fig. 1). The antiserum did not react with the cytosols of the proliferative-phase endometria or with adult male or female sera. The protein in the amniotic fluid samples was measured by rocket immunoelectrophoresis according to the guidelines described by Weeke (1976). Briefly, electrophoresis was carried out on $8.4 \times 9.4 \mathrm{~cm}$ glass plates which were coated with $1 \%$ agarose containing the immunoglobulin fraction of the absorbed antiserum. The immunoglobulin fraction was prepared by addition of solid ammonium sulphate to the antisera to achieve $40 \%$ saturation. Samples were electrophoresed at $8 \mathrm{~V} / \mathrm{cm}$ for $4 \mathrm{~h}$ at $4-7^{\circ} \mathrm{C}$ using barbital buffer (ionic strength $0.025, \mathrm{pH} \mathrm{8.6)}$. After electrophoresis the immunoplates were washed with $0 \cdot 1 \mathrm{M}$-phosphate-buffered saline and stained with Coomassie blue. The progestagen-dependent protein used as reference standard was partly purified from the decidual cytosol as described previously (Joshi et al., 1980b). The concentration of the protein in amniotic fluid was expressed in terms of units $/ \mathrm{mg}$ amniotic fluid protein, one unit being equivalent to the response produced by $1 \mu \mathrm{g}$ of reference protein in the assay. The sensitivity of this method ( $40 \mathrm{ng}$ reference protein per $5 \mu \mathrm{l}$ assay aliquot) was markedly higher than that (100 ng reference protein per $5 \mu \mathrm{l}$ assay aliquot) used in the double immunodiffusion test. Total proteins were determined by the conventional colorimetric procedure of Lowry, Rosebrough, Farr \& Randall (1951).

The statistical significance of the differences in the concentrations of progestagen-dependent protein was evaluated by Student's $t$ test and corrections were made for unequal group size. A value of $P<0.05$ was considered significant.

\section{Results}

The results, summarized in Table 1 , showed a considerable scatter. However, the concentration of protein during Weeks 31-40 was significantly lower than that during Weeks 13.5-20 or 24-30.

Double immunodiffusion tests showed that 69 of the 70 amniotic fluid samples obtained during Weeks 13.5-20 and all 6 samples obtained during Weeks 24-30 contained an immunoreactive progestagen-dependent protein (Text-fig. 1) , but none of 21 samples ${ }_{0}$ collected 
during Weeks 31-40 contained the protein. The protein could not be detected in the cytosols of 10 samples of placental villous tissue, of 15 mid-term placentae, of 20 full-term placentae (Text-fig. 1), or in any of the cytosols of 12 samples of ovary, Fallopian tube, myometrium and cervix obtained during the follicular or luteal phases of the menstrual cycle.

Table 1. Concentrations of total protein and immunoreactive protein in human amniotic fluid

\begin{tabular}{|c|c|c|c|c|}
\hline $\begin{array}{l}\text { Stage of } \\
\text { pregnancy } \\
\text { (weeks) }\end{array}$ & $\begin{array}{l}\text { No. of } \\
\text { samples }\end{array}$ & $\begin{array}{l}\text { Total protein } \\
(\mathrm{mg} / \mathrm{ml})\end{array}$ & $\begin{array}{l}\text { No. of samples } \\
\text { containing the } \\
\text { immunoreactive } \\
\text { protein }\end{array}$ & $\begin{array}{c}\text { Conc. of } \\
\text { immunoreactive } \\
\text { protein } \\
\text { (Units } / \mathrm{mg} \\
\text { protein) }\end{array}$ \\
\hline $13 \cdot 5-20$ & 70 & $\begin{array}{l}4.9 \pm 0.2 \\
(2.6-9.3)\end{array}$ & 69 & $\begin{array}{l}23 \cdot 3 \pm 5 \cdot 9 \\
(1 \cdot 3-64 \cdot 0)\end{array}$ \\
\hline $24-30$ & 6 & $\begin{array}{l}5.0 \pm 0.6 \\
(2.9-6.4)\end{array}$ & 6 & $\begin{array}{l}2.3 \pm 0.7 \\
(1.1-4.7)\end{array}$ \\
\hline $31-40$ & 21 & $\begin{array}{l}2.9 \pm 0.3 \\
(0.3-7.2)\end{array}$ & 20 & Trace* \\
\hline
\end{tabular}

Values are mean \pm s.e.m. (range).

* Less than 0.5 units/mg protein.

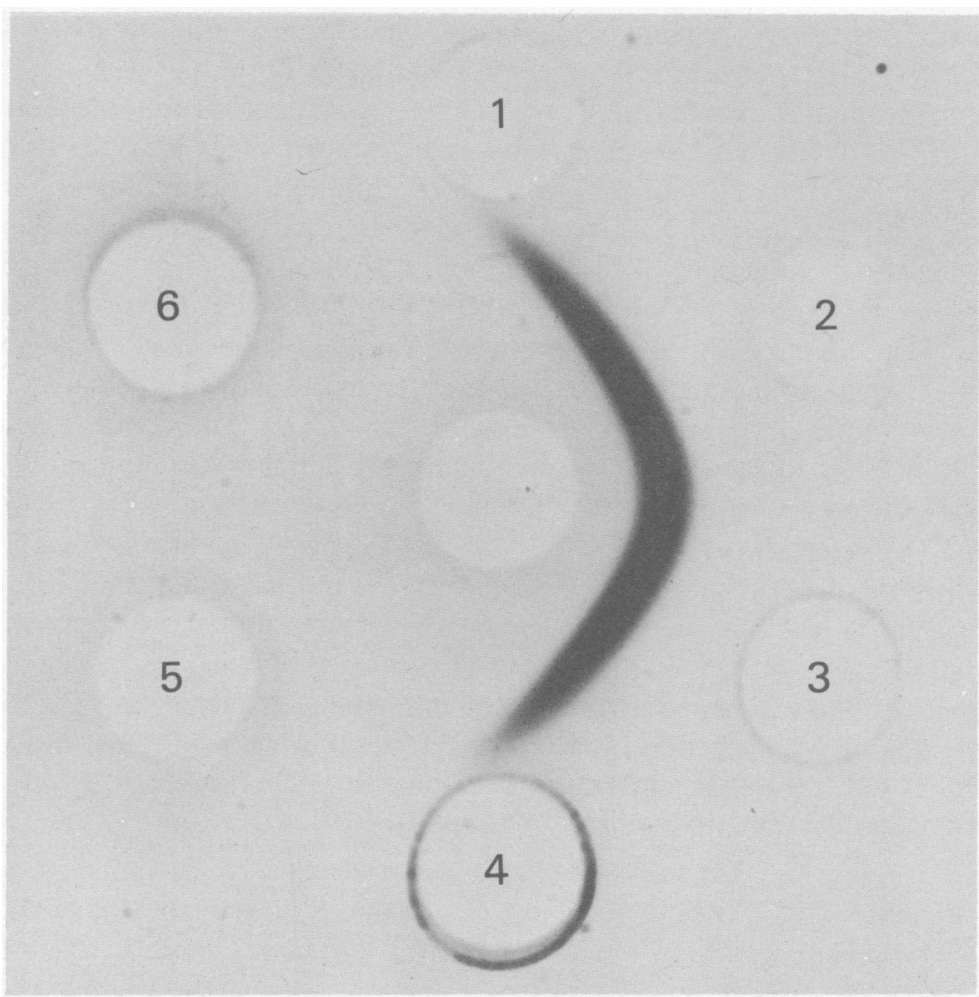

Text-fig. 1. Detection of immunoreactive progestagen dependent endometrial protein in human amniotic fluid by the double immunodiffusion test. The peripheral antigen wells contain (1) adult male serum, (2) cytosol of the decidua-rich tissue of early pregnancy (9 weeks), (3) amniotic fluid (19 weeks), (4) cytosol of the placental villous tissue (9 weeks), (5) cytosol of the mid-term placenta, and (6) cytosol of the term placenta. The centre well contains the antiserum to the protein. 
The measurements of immunoreactive protein by rocket immunoelectrophoresis are given in Text-fig. 2 and Table 1. Maximal levels of the protein in amniotic fluid were encountered during Weeks 15-18 of pregnancy. Thereafter, the levels declined rapidly as pregnancy advanced. Values during Weeks $13 \cdot 5-20$ were significantly higher than those collected during Weeks 24-30. Although the immunoreactive protein was present in 20 of the 21 samples obtained during Weeks $31-40$ the levels were too low $(<0.5$ units $/ \mathrm{mg}$ protein) to be determined accurately.

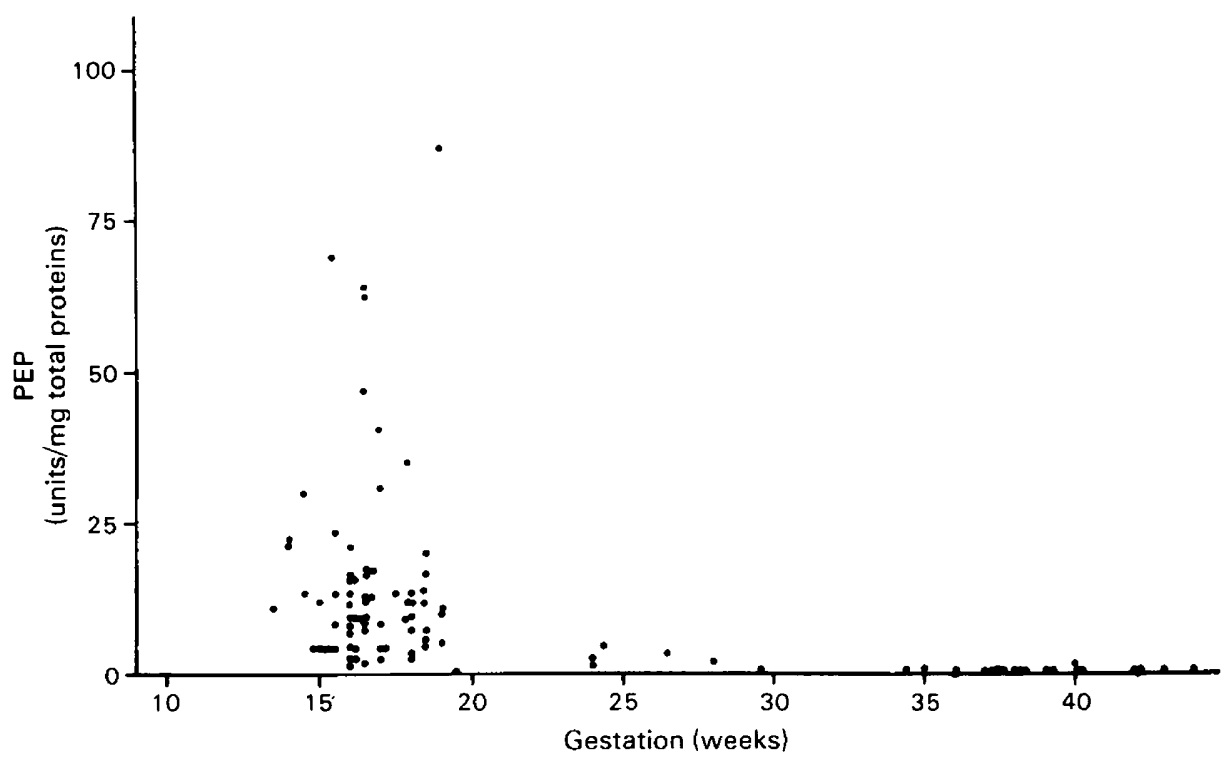

Text-fig. 2. The concentration of immunoreactive progestagen-dependent endometrial protein (PEP) in individual samples of human amniotic fluid.

The presence of the protein was also demonstrated by PAGE. This technique showed that the components derived from amniotic fluid and from the decidua-rich tissue had identical electrophoretic mobility $\left(R_{\mathrm{F}}=0.68, R_{\mathrm{F}}\right.$ of tracking dye $\left.=1.0\right)$ in acrylamide gels. Several samples of amniotic fluid were obtained during Weeks $13 \cdot 5-20$ and pooled before fractionation by Con A-Sepharose chromatography. The immunoreactivity of the amniotic fluid and the decidual fractions was associated with a glycoprotein fraction which was bound to Concanavalin A-Sepharose and could be eluted with $\alpha$-methylglucopyranoside. The isoelectric focussing studies of the glycoprotein fraction derived from the samples demonstrated that the isoelectric point of the immunoreactive components in amniotic fluid was identical to that of the progestagen-dependent protein in the decidua-rich tissue.

\section{Discussion}

This study demonstrates that human amniotic fluid contains an immunoreactive protein which resembles the progestagen-dependent protein of the decidua of pregnancy with respect to its glycoprotein nature, electrophoretic mobility on acrylamide gels and isoelectric point. Therefore, it is logical to assume that the antigenic protein in amniotic fluid is identical to the protein found in the decidua. Although the tissue origin of progestagen-dependent protein in amniotic fluid has 
not been fully determined, the present study excludes the placenta, ovary, Fallopian tube, myometrium and cervix as the major sites of synthesis of this protein. In fact, the protein in amniotic fluid appears to be derived mainly from the uterine decidua of pregnancy where its synthesis has been demonstrated (Joshi et al., 1980a). The observed decline in the concentration of the amniotic fluid protein during the last half of pregnancy may be due to a slower synthesis following the onset of degenerative changes within the decidua, impairment in the mechanism of transplacental transport from the decidua to the amniotic fluid, or removal from the fluid through degradation or by fetal swallowing.

The synthesis and the transport of human uterine proteins in the amniotic sac have not been adequately studied. Sutcliffe, Brock, Nicholson \& Dunn (1978) have indicated that human amniotic fluid contains an alpha-uterine protein or AUP which consists of two sub-units each of molecular weight 25000 . We have demonstrated that the dissociation of progestagen-dependent protein by sodium dodecyl sulphate under reducing conditions yields only one immunoreactive component with a molecular weight of 27000 (Joshi et al., 1980b). This finding and the observation of the present study that the pattern of changes in the levels of the progestagen-dependent protein in amniotic fluid during pregnancy is almost identical to that of alpha-uterine protein (Sutcliffe et al., 1978) strongly suggest that progestagen-dependent protein and alpha-uterine protein are the same protein. Although the biological role of progestagendependent protein is not known, measurement of its concentrations in the amniotic fluid or in peripheral blood may provide information about uterine development during normal and abnormal pregnancies.

We are very grateful to Professor Herbert I. Jacobson for critical review of the manuscript. This study was supported by the Ford Foundation (Grant No. 680-900) and the National Institute of Child Health and Human Development (Grant No. HD-09622).

\section{References}

Joshi, S.G., Ebert, K.M. \& Swartz, D.P. (1980a) Detection and synthesis of a progestagen-dependent protein in the human endometrium. J. Reprod. Fert. 59, 273-285.

Joshi, S.G., Ebert, K.M. \& Smith, R.A. (1980b) Properties of the progestagen-dependent protein of the human endometrium. J. Reprod. Fert. 59, 287-296.

Lowry, O.M., Rosebrough, N.J., Farr, A.L. \& Randall, R.J. (1951) Protein measurement with the Folin phenol reagent. J. biol. Chem. 193, 265-275.
Sutcliffe, R.G. (1975) The nature and origin of the soluble proteins in human amniotic fluid. Biol. Rev. 50, 1-33.

Sutcliffe, R.G., Brock, D.J.H., Nicholson, L.V.B. \& Dunn, E. (1978) Fetal and uterine-specific antigens in human amniotic fluid. J.Reprod. Fert. 54, 85-90.

Weeke, B.V. (1976) Rocket immunoelectrophoresis. In $A$ Manual of Quantitative Electrophoresis, pp. 37-46. Eds N. H. Axelsen, J. Kroll \& B. Weeke. Universitetsforlaget, Oslo.

Received 15 January 1980 